II. Spine cells are widely distributed in the upper epidermis C. oxyandra, C. Vanheurckii and C. melanocarpa

III. Neither spine cells, protuberances nor hairy cells are found, except in the margin C. quadriflora and C. mira

IV. Stomata are distributed widely in the upper and under epidermis C. lanceolata

3. An analytical key to the four species of the first group as follows :-

1 Hairy cells occurring in the upper or under epidermis -2 Hairy cells never occurring in the epidermis -C. globularis Hairy cells occurring in the upper and under epidermis. Stomata found in the upper epidermis near the margin of the leaves

2

Hairy cells occurring in the upper epidermis only. Stomata never found in the upper epidermis 3 Upper epidermal cells $20-50 \mu$ in length. Hairy cells long (average length about $250 \mu$ ). Stomata $20 \mu$ in length

3

Upper epidermal cells $50-100 \mu$ in length. Hairy cells short (average length about $100 \mu$ ). Stomata $35 \mu$ in length

-C. nanella

\title{
硫黄紅色細菌及ビ無硫黄紅色細菌ノ相互 關係二關スル知見
}

\author{
中 村 浩 \\ Hirosi Nakamura: Zur Kenntnis des gegenseitigen Zusammcnhangs \\ von Thio- un'l Athiorhodobakterien.
}

Eingegangen am 5. Februar 1938.

緒言

細菌二依儿光合成ノ研究八最近二於ヶル植物生理學上, 興味アル問題ノーツトシ ラ注目七ラレ, van Niel, F. M. Muller, H. Gaftron, P. A. Roelofren, V. CzURDA 及ビ C. S. FRENCH 等八相繼イデ其研究ヨ發表シ夕。著者モ數年來此問題 八跨究二從事シ, 既二無硫黄紅色細菌ノ二種 Rhodobacillus palustris 及ビ Rhodospirillum giganteum =就イテソノ物質代謝生理二關スル獨自ノ研究习發表シタ 
ガ，著者二依ツテ始メテ明カニサレタ點八是等ノ細菌ガ光合成ノ結果酸素ヨ放出ス ル事實 ノソレト異ナル事ナク, 光合成二關スル柴田敎授說ニョリ說明サレ得ル事ヨ實證シ

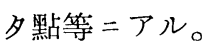

細菌ノ光合成二關シ VAN NIEL 等ハコレヨ通常ノ綠色植物ノソレトハ異ナル特殊 ナ光合成卜解稡スルノデアルガ，VAN NIEL 等ノ說二反對セル著者等ノ此見解二對 シCzurda, P. A. Spoenr 等八替意习表シテ居ル。

最近更二硫黄紅色細菌ノ一種 Chromatium minutissimum 二就イテソノ物質代謝

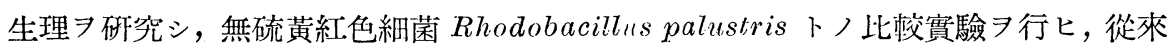
疑問ノ僙殘サレテ居夕硫黄紅色細菌及ビ無硫黄紅色細菌間つ相互關係二關スル問題 二對シ賽驗的二見出シタ新事實カラ解明 7 與フル事ガ出來タト信ズルノデ, 以下コ レニ就イテ論述シタイト思フ。

\section{材料及ビ㖃究法}

研究材料トシテ八無硫黄紅色細菌ノ一種 Rhodobacillus palustris 及ビ硫黄紅色 細菌ノ一種 Chromatium minutissimum 選ンダ。前者八著者等, 㸴究室=數年來 純粹培養サレテキルモノデアリ，後者八最近著者ガ泥土中ヨリ分離シ純粹二培養シ タモノデアル。Rhodobacillus/培養二ハMoLISCH 氏ノペプトン・グリセリン培養 基尹用ヒタ。ソノ處方八次ノ如クデアル。

$\begin{array}{lrlr}\text { ペプトン } & 5 \mathrm{~g} & \mathrm{~K}_{2} \mathrm{HPO}_{4} & 0.5 \mathrm{~g} \\ \text { グリセリン } & 5 \mathrm{~g} & \mathrm{FeSO}_{4} & \text { 悢跡 } \\ \mathrm{MgSO}_{4} & 0.5 \mathrm{~g} & \text { 蒸溜水 } & 1000 \mathrm{cc} .\end{array}$

培養液入 $300 \mathrm{ec}$ 大エルレンマイエル・コルベン $=200 \mathrm{ce}$ 程洏タシ, 滅菌, 接種後, 好氣狀態つ儘光箱中 $=30-35^{\circ} \mathrm{C}=$ 茞ク。接種後 4-5 日デ全液赤變 スル程繁殖八良好 デアル。Chromatium ノ培養ニ八 VAN NIFL Eノ培養基习用七夕。ソ/處方八次二 示ス。

$\begin{array}{lllr}\mathrm{NH}_{4} \mathrm{Cl} & 1 \mathrm{~g} & \mathrm{Na}_{2} \mathrm{HCO}_{3} & 1 \mathrm{~g} \\ \mathrm{~K}_{2} \mathrm{HPO}_{4} & 1 \mathrm{~g} & \mathrm{Na}_{2} \mathrm{~S} \cdot 9 \mathrm{H}_{2} \mathrm{O} & 1 \mathrm{~g} \\ \mathrm{MgCl}_{2} & 1 \mathrm{~g} & \text { 水 } & 1000 \mathrm{cc} .\end{array}$

$\left(\mathrm{NaHCO}_{3}\right.$ Z代 $\mathrm{Na}_{2} \mathrm{~S} \cdot 9 \mathrm{H}_{2} \mathrm{O}$ 八別二減菌ス $)$

培養液入 $100 \mathrm{ec}$ 入長形試驗管 $=70 \mathrm{ec}$ 程满シ,滅菌, 接種後, 細谷・岸野式嫌氣培飬 器二入レ水素氣或八德田氏混合氣 $\left(\mathrm{H}_{2} \mathrm{~S}: \mathrm{CO}_{2}: \mathrm{H}_{2}=1: 2: 27\right)$ 7通ジ, 光箱中 $=30-$ $35^{\circ} \mathrm{C}$ 二監ク，7-10 日後二細菌ノ繁殖二因り全液八桃色 呈スルニ至ル。

實驗使用前二細菌习各培養㼛 $コ$ 遠心器/助ケニョリ集又 3-4 包蒸溜水 滌シ 0.9 ペーセント食監水中二想濁セシメル。

物質代謝生理二關スル研究八WARBURG 氏檢壓法二低ツ夕。檢壓計容器二八細菌 奬濁液, 燐酸緩衝液, 添加物質等八次>割合デ裝備シタ。

主室中： $0.5 \mathrm{ccm}$ 細菌賏濁液及ビ $0.5 \mathrm{~cm} \mathrm{M} / 4$ 燐酸綏衝液及ビ $1.0 \mathrm{cem}$ 蒸溜水 
側室中： $0.5 \mathrm{ccm}$ 添加物質溶液

內室中： $0.5 \mathrm{cem} 5 \%$ 梊性加里，但炭酸吸收测定ノ場合八 $0.5 \mathrm{ccm}$ 水。

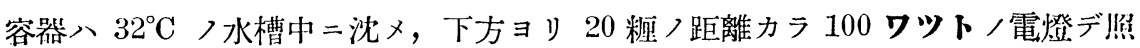


シテ用ヒル。

顯微鏡的觀察ハアニリン靑染色法ニ低ツタ。

\section{硫黃紅色細菌及ビ無硫黃紅色細菌ノ培養上ノ諸性質ノ比較}

硫黄紅色細菌及ビ無硫黄紅色細菌八其二細胞內二細菌苝綠素 (Bacteriochlorophyll) 站ビ二數種カロチノイド色素习含有シ，且分布的二見テモ互二混在シテ棲息 スルモノデアルガ, 前者八通常アウトトローフ二生活シ, 且體內二硫黄粒ヨ含蓄ス ルニ仅シ，後者ガヘテロトローフ二生活シ，日體內二硫黄粒习含蓄シナイ點カラ此 网何者八從來分類學上明膫二區別サレテ+タノデアル。然ル二MOLISCH 八前二硫黄 紅色練菌 (Chromatium) ヨヘテロトローフ二培養シ得儿事ヨ報ジ，VAN NIEL 及ビ MULLER 八同ジク硫黄紅色細菌 (Thiocystis 及ビ Chromatium) ガ種々ナル有機酸監 フ含么培養基上二繁殖スル事ヨ觀察報告シテキル。著者八硫黄紅色細菌 (Chroma-

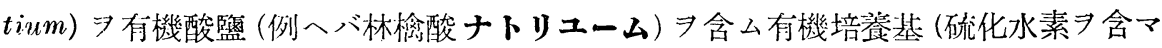
ズ）中二發有シ得ル事ヨ觀祭シタ。從ツテ硫黄紅色細菌及ビ無硫黃紅色細菌/网都 アソノ發奇ガアウトトローフデアルカヘテロトローフデアルカノ觀䁫ヨり區别スル 事八夏當习缺ク事トナル。

次二网者ノ硫化水素二關スル關係デアルガ，硫黄紅色細菌ガ通常り/發青二硫化


アルガ，著者ノ前ノ報告二明カナ如ク，硫化水素入無硫黃紅色細菌二無害デアル， ミナラズ，長期間硫化水素中二培養シタモノ八硫化水素ヨソノ光合成二用七ル事ガ 出來儿點 明カニシタ。從ツテ無硫黄紶色細菌モ亦硫黄紅色細菌卜同ジクアウトト ローフニモ生活シ得ルモノデアリ，コノ點カラモ网者习明碓二區別スル事八出來ナ イノデアル。

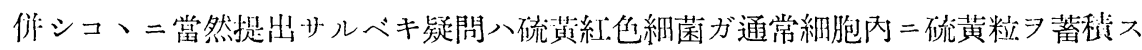
ルニ文シ無硫橫紬色細菌ガ硫化水素习ソノ物質代謝二用七ル場合モ通常細胞內二硫

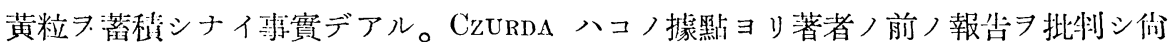
未解沈ノ問題ガコノ點ニアル事ヨ指摘シタガ，コノ諭點ニ關シテハ後ニ詳述スル。

\section{硫黃紅色細菌及ビ無硫黃紅色細菌ノ光合成二關スル比較研究}

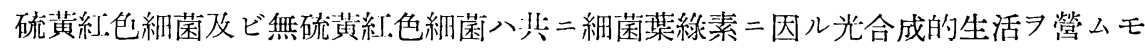
ノデアルガ，前者ガ通常アウトトローフニ生活スルニ反シ，後者八通常へテロトロ ーフニ生活スル。VAN NIEL 八細菌ノ光合成及ビ反應機作 7 Wieland 說又ハKLUYVER-DON KER 說二基ク酸化還元反應トシテ說明シ，次ノ式ヨ提出シタ。 


$$
\mathrm{CO}_{2}+2 \mathrm{H}_{2} \mathrm{~A}=\left(\mathrm{CH}_{2} \mathrm{O}\right)+\mathrm{A}_{2}+\mathrm{H}_{2} \mathrm{O} .
$$

コ、 $=\mathrm{H}_{2} \mathrm{~A}$ 八水素供與體 示シ, 水分子, 硫化水素分子, 其他或種ノ有機酸素等ガ 水素供與體トナル。從ツテ通常ノ綠色植物ノ場合入光合成過程二於ヶル水素供與體 トシテハ常二水分子ガ働キ, ソノ結果フオルムアルデヒドト酸素ヨ生ズルガ, 細菌 つ場合八硫化水素或八有機酸ガ水素供與體トシテ働キフオルムアルデヒドト水素供 與體自身ノ酸化生成物(例へバ硫化水素ガ水素供與體〉場合八硫黃) 7 生ジ酸素八放 出シナイ。要スル V VAN NIEL 說ニヨレバ細菌ノ光合成二於テハソノ反應過程二於 テ水分子以外ニソレゾレ特殊ナ水素供與體ヨ考へルノデアル。

コレニ反シ著者等ノ見解八光合成八細菌或八高等植物/如何 子ヨ水素供與體トシ

$$
\mathrm{H}_{2} \mathrm{CO}_{3}+4 \mathrm{H}_{2} \mathrm{O}=\left(\mathrm{CH}_{2} \mathrm{O}\right)+2 \mathrm{II}_{2} \mathrm{O}+4 \mathrm{OH}
$$

ナル反應式二從ヒ, フオルムアルデヒド以外二中間生成物トシテ四籄ノ $\mathrm{OH}$-基フ生 ズル(柴田說)。通常)綠色植物二於テハコノ四箇ノ $\mathrm{OH}$-基ガ $4 \mathrm{OH}=2 \mathrm{H}_{2} \mathrm{O}_{2}$ /如ク 反應シ過酸化水素 卜 $\mathrm{O}_{2}=$ 分解サレル。硫化水素ガ存在スル場合二八光合成〉主反雇八上ノ場合卜同. 樣デ先ヅ四䇢, OH-基ア生ジ

$$
40 \mathrm{H}+\mathrm{H}_{2} \mathrm{~S}=4 \mathrm{H}_{2} \mathrm{O}+2 \mathrm{~S}
$$

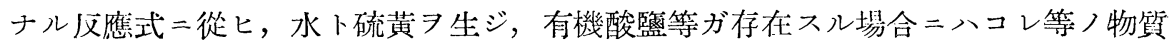
ガ一旦脫水素障素／作用二ヨリ脫水素サレ，生ジタ H-原子ガ

$$
4 \mathrm{OH}+4 \mathrm{H}=4 \mathrm{H}_{2} \mathrm{O}
$$

ノ如ク反應シ直二水トナル。又分子狀水素ガ存在スル場合二八四箇ノ OH- 基八直二 分子狀水素卜反應シ

$$
4 \mathrm{OH}+2 \mathrm{H}_{2}=4 \mathrm{H}_{2} \mathrm{O}
$$

トナル。

斯クノ如ク著者等つ見解二低レバ光合成ノ主應入如何ナル埸合二モ其通デアッ テ, 硫化水素, 有機酸鹽, 分子狀水素等, 介在スル場合, 光合成ハコレフ特殊ナモ ノト解辪七ズ，當然起り得ベキ侧及雇トシテア解セラレルノデアル。從ツテコ/侧 反應トシテ唀起サレル諸反應八生物體/生活スル㭴質/狀態, 或ハコレ等媒質中


リ汽定セラレルコト、ナル。

コ、二一例ヨ门用スレバ，著者八前二硫化水素含有基中二生活スル二三下等藻類 (Oscillatoria 及ビ Pinnularia) カ硫黄紅色細菌卜同ジク, ソフ光合成二硫化水素 用ヒ，ソノ絬果ソノ副産物トシテ細胞內二硫黃粒ガ出現スル事ヨ立證シタガ，コ， 事實入 VAN NIEL 說ニ依レバ澡類/場合二モ水分子以外二硫化水素ガ水素供與體卜 シテ働キ得ルコト、ナリ，藻類/光合成二於ケル一買例トシテ解釋シナケレバナラ ナイ二反シ，著者等つ見解ニヨレバ，カ、ル現象八當然起リ得ベキ普通ノ現象トシ テア解サレル。

サテ次二種タナル物筫ガ存在スル場合ノ硫黄紬色細菌及ビ無硫黃紅色細菌/光合 
成ノ比較實驗フ記述スル。第一圖八硫黃紅色細菌 (Chromatium) 及ビ無硫黄紅色細 菌 (Rhodobacillus) ノ光合成 7 脂肪酸鹽（M/30 酪酸加里）ノ存在ノ下二測定シタ結 果デアルガ，ソノ炭酸吸收八兩者共二著シイ。闇二於テ曲線ガ上昇ヨ示スノ八細菌 自體ノ娥氣呼吸 $=ヨ リ$ 炭酸瓦斯ガ放出サレル爲デアル。コ/現像八著者ガ前二解明 セル如ク光合成ノ主反應二於テ中間生成物トシテ生ズル四箇 $>\mathrm{OH}$-基卜脂肪酸脫水 素酵素ノ作用 $=ヨ$ リ脂肪酸ガ脫水素サレ生ジタ水素原子卜ノ反應ニヨリ說明サレ得 ルノデアルカラ, 网種ノ細菌ガ脂肪酸脫水素酵素习共有スル事ガ明カデアル, 佮コ 事實八脂肪酸鹽ヨ水素供與體トスルメチレン靑還元／實驗（THUNBERG 法ニョル） カラモ確認サレタ。

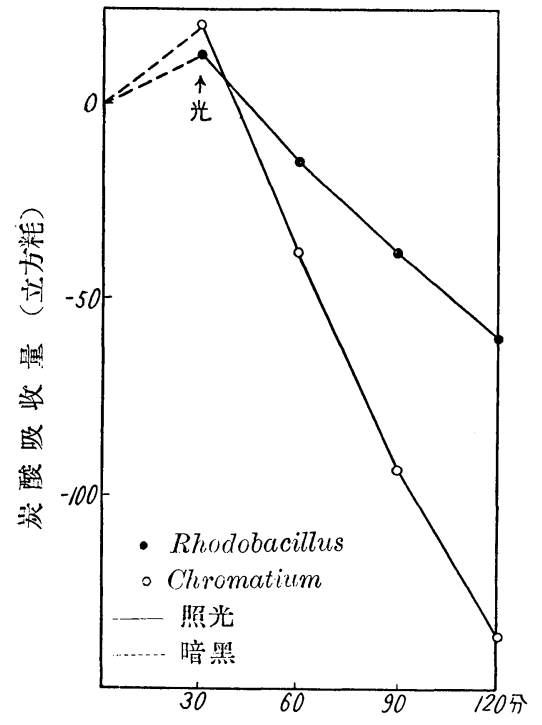

第 一 一 滴

脂肪酸㢳, 存在スル場合/光合成 細萄乾燥量：Rhodobacillus 約 $12 \mathrm{mg}$. Chromatium 約 $14 \mathrm{mg}$ 容器瓦斯柼: $95 \% \mathrm{~N}_{2}+5 \% \mathrm{CO}_{2}, 32^{\circ}$.

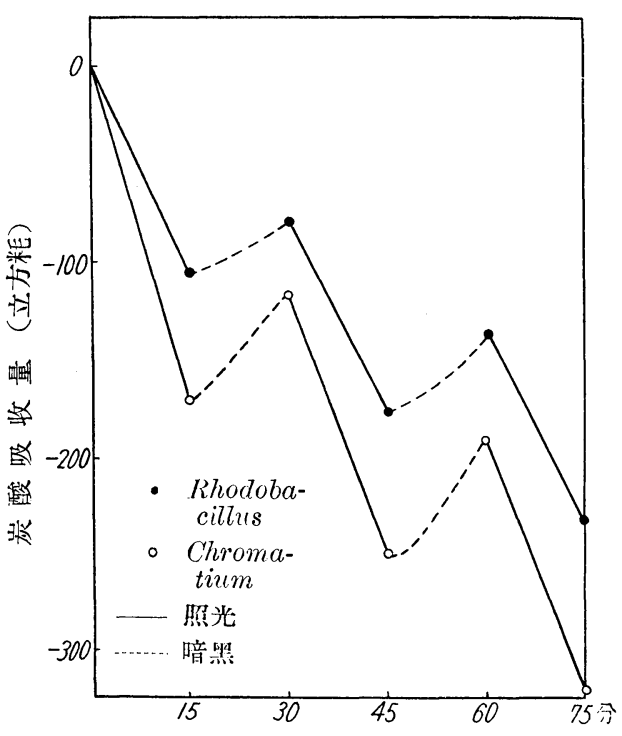

第 二 圖

硫化水素/存在スル場合/光合成 細菌乾燥量：Rhodobacillus 約 $13 \mathrm{mg}$. Chromatium 約 $16 \mathrm{mg}$. 容器瓦斯腔： $95 \% \mathrm{~N}_{2}+5 \% \mathrm{CO}_{2}, 32^{\circ}$.

次二硫化水素ガ存在スル場合/硫黄紅色細菌及ビ無硫黄紅色細菌ノ光合成 7 比较 實驗スルト, 光合成ノ中間生成物トシテ生ズル $\mathrm{OH}$-基卜硫化水素卜/反應ガ网者共 同樣二起ル事ガ確メラレタ(第二圖參照)。コ、ニOH-基卜硫化水素卜ノ反應)結果 硫黃习生ジ，顯微鏡的ニ細胞內ニコレガ觀察サルベキデアルガ硫黄紅色細菌ニハコ レガ観察サレルガ，無硫黃紅色細菌二八通常コレガ觀察サレナイ，コノ點ニ關シテ 八次二詳論スル。

\section{硫黃紅色細菌及ビ無硫黃紅色細菌ノ硫莖及ビ硫化物ノ還元作用}

著者八前 $=$ 無硫带紅色細菌 (Rhodobacillus) ガ水素化酵素 (Hydrogenase) 7 含有 シ，水素氣中二於テ硝酸鹽及ビメチレン靑ヨ還元スル事ヨ報ジタガ，最近該菌ガ同 
酵素ノ作用 $=ヨ$ リ上ノ物質ノ他フマール酸監, 亞硝酸監及ビ酸素习還元スル事ヨ 見出シ夕侗同樣ナ現象ガ硫黃紅色細菌 $($ Chromatium $)$ 二就イテモ確メラレタ。

山縣春次氏及ビ著者〉研究 $ニ ョ リ$ 水素化ナル現象八次ノ如ク說明サレル，郎チ

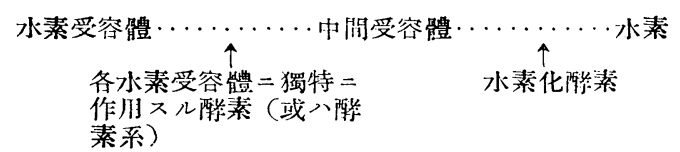

從ツテ水素化睹素ガ關與スル水素化ナル現象二水素受容體トシテ墈ク物質入，該物 質二獨特二作用スル陵素(或ハ愫素系)ノ存否如何ニョツテ異ナツテ然ルベキモノデ アル。硫黄紅色細菌及ビ無硫黄紅色細菌八其二水素化酵素习含有スルガ，水素化作 用二於テ水素浽容體トシテ働ク物質ガ珙ナルヤ否ヤ, 若シ罢ナルトスレバ該物質二


驗フ行ヒ重要ナル結果

實驗八水素化作用二於ケル水素受容體卜シテ硫酸監、チ才流酸盬及ビ硫黄ヨ與へ 行ツ夕。先ヅ硫酸監 フ水素受容體卜スル場合，硫黄紬色細菌 (Chromatium) デ八著 シイ水素吸收ガ 水素氣中二於テ見ラレル二文シ，無硫黄紅色細菌 (Rhodobacillus) デハ水素吸收ハ全然見ラレナイ。次二チ才硫酸監ヨ水素受容體下スル場合八网者共 二著シイ水素吸收ガ見ラレル。次二硫黄习水素妥容體トスル場合二八興味アル事二 八硫黄紅色細菌ハコレラ用ヒ得ナイニ反シ。無硫黃紅色細菌ハコレヨ水素受容體卜

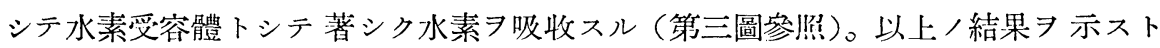
次ノ表ノ如クナル。

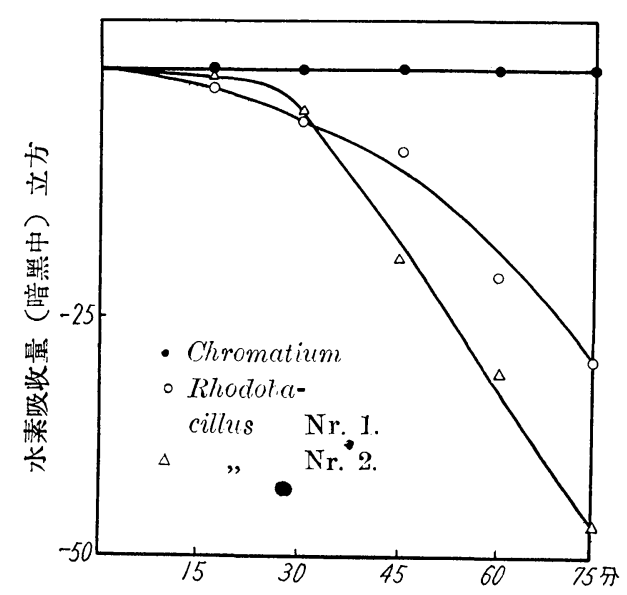

第三圖

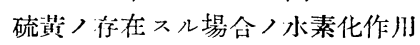

細莉战燥量：Rhodobacillus 約 $8 \mathrm{mg}$. Chromatium 約 $10 \mathrm{mg}$.

容器瓦斯膑：水素, $32^{\circ}$.

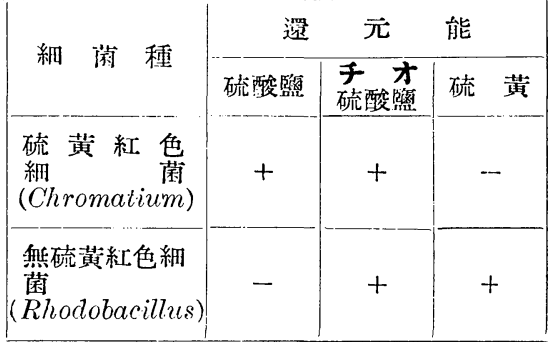

コノ實驗デ明カナ如ク 硫黄紅色細菌ガ 細胞內二硫黄粒ヨ含蓄 スルニ反シ無硫 黃紅色細菌ガコレヨ含蓄シナイ事實八 前者ガ硫黄 $\ni$ 還元スル能力，即于硫黄 還元酵素(或八亚素系)ヨ有シナイ二反 シ後者ガコレラ有スルトナス事カラ容 易二了解サレル。從ツテ 無硫黃紅色細 菌二於テ八譬へ光合成二於テ 硫化水素 ヨ酸化シテ硫黄习生ジテモ硫黃八直二 再ビ硫化水素二還元サレ細胞內二蓄積シナイ理デアル。從ツテ從來形態學的二重大 
ナ相造點デアツタ細胞內ノ硫黄粒ノ有無入單二一酵素(或八睹素系)ノ存否如何二歸 ス事ガ出來ル。

嘗テ GAFFRON 八硫黃紅色細菌ノ一種 Thiocystis ガ硫酸鹽ク闇二於テ還元シ硫化

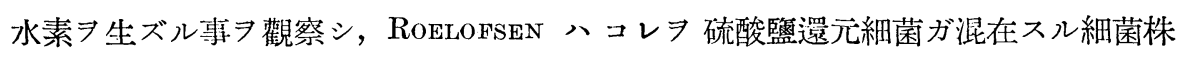
ノ不純ノ爲トナシ，後=VAN NIEL 八同樣ナ實驗习行七紅色硫黃細菌 (Thiocystis) 八確カ二闇二於テ硫酸監ヨリ硫化水素习生ズルガ, コノ現象八水素氣中二於テノミ 觀察サレル事ヨ報ジ，且ソノ理由八不明デアルト述ベタガ，コレ等ノ觀察入著者ノ 實驗結果ヨリ明膫二說明シ盡サレルモノデアル。

\section{結言}

以上述べ諸事實ヨリ結論七ラレル事八硫黄紅色細菌及ビ無硫黄紅色細菌ノ主ナル

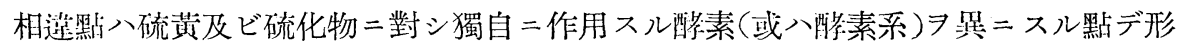
態的二前者ガ硫黄习細胞內二含蓄シ，後者ガコレヨ有サナイノ八前者八硫黄還元瞵 素习缺キ後者ガコレヨ有スルトナス事カラ了解サレル。其他/物質代謝, 特二光合 成二於テハ兩者八極メテ類似シタ關係ニアリ, 從ツテコノ网者ヨ從來/如ク各異ナ ル科二區別スル事入穻當デナイト考へル。

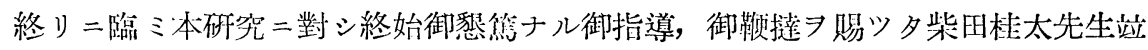

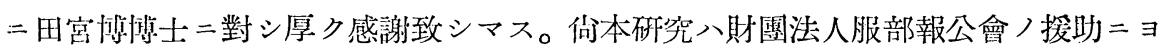
ツテ行ハレタモノデアル事习附記スル。

\section{東京帝國大學理學部植物學敎室}

\section{引用文献}

W. Bavendamm: Ergebnisse der Biologie, 13 (1936), 1.

V. Czurda: Arch. f. Mikrobiol., 7 (1936), 110; 8 (1937), 99.

C. S. Frencin: Science, 84 (1936), 575; Journ. Gen. Physiol., 20 (I937), 711 ; 21 (1937), 715.

H. Gaffron: Biochem. Ztschr., 260 (1933), 1; 269 (1934), 447; 275 (1935), 1; Naturwiss., 24 (1936), 103; 25 (1937), 715.

中村 溜: Acta Phytochim., 9 (1937), $189 ; 9$ (1937), 231；10 (1937-38), 211; Bot. Mag. (Tokyo), 本誌 51 (1937), 529 .

P. A. Roelofsen: Proc. Kon. Akad. Wetensch. Amsterdam, 37 (1934), 660 ; On Photosynthesis of the Thiorhodacene. Diss. Utrecht, 1935.

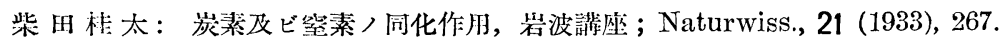

德用行三: Bot. Mag. (Tokyo), 本誌 50 (1936), 393.

C. B. van Niel: Arch. f. Mikrobiol., 3 (1931), 1; C. B. van Niel u. F. M. Muller; Rec. trav. botan. néerl., 28 (1931), 245; F. M. Muller : On the Metabolism of the Purple Sulphur Bacteria in Organic Media Diss. Utrecht, 1933; C. B. vaN Niel : Arch. f. Mikrobiol., 7 (1936), 323; Les photosynthèses bactériennes, 1936, Nancy. 


\section{Résumé.}

Die Stoff.wechseltypen von Thio- und Athiorhodobakterien wurden vergleichend untersucht. Der Unterschied von beiden Typen ist wohl kein absoluter, wenn man vom Verhandensein der Schwefelkügelchen im Zellinnern absieht. Das Vorkommen oder Nichtvorkommen des Schwefelkügelchens im Zellinnern bei den Thio- bzw. Athiorhodobakterien hängt lediglich von der An- oder $\Lambda$ bwesenheit eines Enzyms oder Enzymsystems ab, das auf den gebildeten Schewel spezifisch reduzierend einwirkt. 